\title{
Association between meteorological indicators and COVID-19 pandemic in Pakistan
}

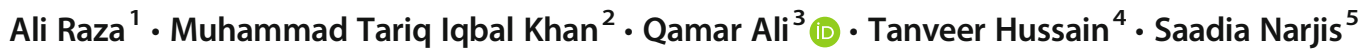

Received: 17 June 2020 / Accepted: 9 October 2020 / Published online: 14 October 2020

(C) Springer-Verlag GmbH Germany, part of Springer Nature 2020

\begin{abstract}
This study was designed to investigate the impact of meteorological indicators (temperature, rainfall, and humidity) on total COVID-19 cases in Pakistan, its provinces, and administrative units from March 10, 2020, to August 25, 2020. The correlation analysis showed that COVID-19 cases and temperature showed a positive correlation. It implies that the increase in COVID-19 cases was reported due to an increase in the temperature in Pakistan, its provinces, and administrative units. The generalized Poisson regression showed that the rise in the expected log count of COVID-19 cases was 0.024 times for a $1{ }^{\circ} \mathrm{C}$ rise in the average temperature in Pakistan. Second, the correlation between rainfall and COVID-19 cases was negative in Pakistan. However, the regression coefficient between the expected log count of COVID-19 cases and rainfall was insignificant in Pakistan. Third, the correlation between humidity and the total COVID-19 cases was negative, which implies that the increase in humidity is beneficial to stop the transmission of COVID-19 in Pakistan, its provinces, and administrative units. The reduction in the expected log count of COVID-19 cases was 0.008 times for a $1 \%$ increase in the humidity per day in Pakistan. However, humidity and COVID-19 cases were positively correlated in Sindh province. It is required to create awareness among the general population, and the government should include the causes, symptoms, and precautions in the educational syllabus. Moreover, people should adopt the habit of hand wash, social distancing, personal hygiene, mask-wearing, and the use of hand sanitizers to control the COVID-19.
\end{abstract}

Keywords Dose-response $\cdot$ Generalized additive model $\cdot$ Humidity $\cdot$ Temperature $\cdot$ Rainfall $\cdot$ Generalized Poisson regression

\section{Introduction}

The public health and global economy faced difficulties due to the outbreak of novel severe acute respiratory syndrome coronavirus 2 (SARS-CoV-2), which is responsible for coronavirus disease (COVID-19) (Briz-Redón and Serrano-Aroca
2020). In December 2019, the COVID-19 was initially reported in Wuhan, China. Its common symptoms are cough, fever, fatigue, and shortness of breath. It is generally transmitted between human beings through droplets or physical contact (Xie and Zhu 2020). On March 11, 2020, the World Health Organization (WHO) has officially declared COVID-19 as

Responsible editor: Lotfi Aleya

Qamar Ali

qamarali2402@gmail.com

$$
\begin{aligned}
& \text { Ali Raza } \\
& \text { maharalirix44@gmail.com } \\
& \text { Muhammad Tariq Iqbal Khan } \\
& \text { tariqiqbal88@yahoo.com } \\
& \text { Tanveer Hussain } \\
& \text { tanveer.hussain@ vu.edu.pk } \\
& \text { Saadia Narjis } \\
& \text { saadianarjis@hotmail.com }
\end{aligned}
$$

Department of Molecular Biology, Virtual University of Pakistan, Lahore, Pakistan

2 Department of Economics, Government Postgraduate College, Jaranwa la-37200, Pakistan

3 Department of Economics, Virtual University of Pakistan-Faisalabad Campus, Faisab ad-38000, Pakistan

4 Department of Molecular Biology, Virtual University of Pakistan, Lahore 54000, Pakistan

5 Department of Economics, Government College University, Faisalabad 38000, Pakistan 
pandemic because COVID-19 affected more than 200 countries, and accountable for $34,724,785$ confirmed cases (World Health Organization (WHO) 2020). In severe cases, COVID19 causes pneumonia, kidney failure, acute respiratory syndrome, and death (Tosepu et al. 2020).

In Pakistan, the first COVID-19 case was confirmed on February 26, 2020. After that, an increase in COVID-19 cases was observed in Pakistan (Syed and Sibgatullah 2020). The coronavirus confirmed cases till October 04, 2020, were 314,616 with 6513 deaths in Pakistan (Government of Pakistan (GOP) 2020a). The WHO warned that Pakistan might be the next hub of COVID-19 without the implementation of necessary precautionary measures. However, community perception about risk of COVID-19 infection is not satisfactory because the population does not adequately follow the preventive measures. The situation of COVID-19 becomes serious in Pakistan (Fig. 1). The Ministry of Health has proclaimed guidelines for virus control according to the recommendations of WHO (Khan et al. 2020). The governments tried to control the transmission by imposing lockdowns and quarantines due to non-availability of medical treatment (Gupta et al. 2020). The communities have been directed to stay in the home, frequently wash their hands, avoid touching their faces, avoid to visit public places, and maintain 1-2 m distance (social distancing) to control the COVID-19 transmission (Carico et al. 2020).

The epidemiological dynamics of many infectious diseases depend upon environmental factors (Shi et al. 2020). Dalziel et al. (2018) told that the transmission of viruses was influenced by various factors like humidity, temperature, and population density. The outbreak of SARS was also linked with environmental indicators (Sobral et al. 2020). Epidemiological research revealed the linkages between meteorological indicators and COVID-19 but the findings were not clear (Wu et al. 2020). Literature (Gale et al. 2010; Stott 2016) revealed that climate change was linked with the emergence and spread of infectious diseases. Dry or cold weather was favorable for viral diseases like influenza. The SARS epidemic was reduced due to warm season and finished in July 2003. The COVID-19 was mostly observed in the countries, located in low-temperature regions (Liu et al. 2020). The COVID-19 spread was normally observed in areas having low annual average temperatures $\left(37-63^{\circ} \mathrm{F}\right.$ or $\left.3-17^{\circ} \mathrm{C}\right)$. Chinese researchers mentioned the link between humidity, temperature, and COVID-19 outbreak. The COVID-19 spread was lower in warm and humid regions of China. Researchers from Finland and Spain reported that $95 \%$ of global infections take place between 2 and $10^{\circ} \mathrm{C}$, and in dry climates. The COVID19 spread was also reported in hot and humid conditions like Malaysia, Indonesia, and Singapore (Ahmadi et al. 2020).

Meteorological indicators could affect environmental stability, which further influenced the viability of viruses. The humidity and temperature showed a significant impact on
COVID-19 spread (Chen et al. 2020). In China, both relative humidity and temperature significantly influenced the transmission of COVID-19 (Wang et al. 2020a). Sajadi et al. (2020) also mentioned the nexus between temperature, humidity, and respiratory viruses. The variations in the temperature and humidity also influenced the COVID-19 mortality (Ma et al. 2020). Prata et al. (2020) stated that it is hypothesized that variations in average temperature could significantly affect the COVID-19. Jahangiri et al. (2020) wrote that ambient temperature could be a crucial transmissibility factor behind COVID-19.

Tosepu et al. (2020) explored the correlation between the COVID-19 pandemic and weather indicators (minimum temperature, maximum temperature, average temperature, and rainfall) in Jakarta, Indonesia. Spearman-rank correlation confirmed a significant correlation between COVID-19 and temperature. In Korea, the transmission of influenza was associated with relative humidity and low temperature. Studies also highlighted that COVID-19 was linked with meteorological factors (Ma et al. 2020). Şahin (2020) explored the linkages between COVID-19, population, and meteorological indicators (temperature, wind speed, dew point, and humidity) in Turkey. The Spearman's correlation confirmed the highest correlations score for population, temperature, and wind speed. Bashir et al. (2020) revealed the link among climate indicators (average temperature, average humidity, rainfall, air quality, and wind speed) and COVID-19 in New York, USA. Correlation statistics confirmed a significant link between climate conditions and COVID-19.

However, no study explored the association between meteorological indicators and COVID-19 in Pakistan. The contribution of this study is (a) it first time examined the relationship between meteorological indicators and COVID-19 in Pakistan, (b) it first time examined the relationship between meteorological indicators and COVID-19 in four provinces and three administrative units in Pakistan, and (c) it used the generalized models to investigate the impact of average temperature, rainfall, and humidity on COVID-19 cases. Therefore, this study explored the impact of meteorological variables (temperature, average rainfall, and humidity) on COID-19 cases and infection rate.

\section{Methods}

\section{Study area}

This study was designed to examine the link between meteorological variables and COVID-19 cases in Pakistan. Pakistan ranked among top 20 countries, which were affected by the COVID-19. Pakistan is the 6th most populated country and ranked 36th according to the area in the world. Pakistan is an agriculture-based developing country, having 1629 USD per 


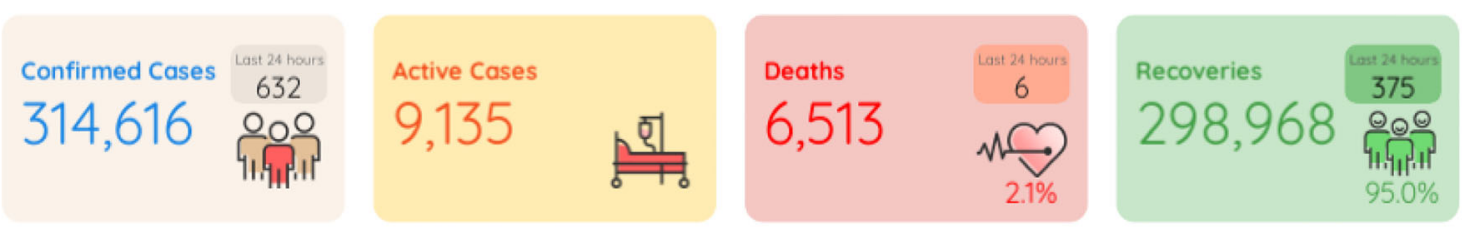

\begin{tabular}{l|c|c|c|c|}
\hline AJK & $\begin{array}{c}\text { Confirmed } \\
\text { Cases }\end{array}$ & $\begin{array}{c}\text { Active } \\
\text { Cases }\end{array}$ & Deaths & $\begin{array}{r}\text { Recoveries } \\
\text { 走 }\end{array}$ \\
\hline Balochistan & 2,816 & 332 & 76 & 2,408 \\
\hline GB & 15,371 & 823 & 146 & 14,402 \\
\hline Islamabad & 16,766 & 549 & 183 & 16,034 \\
\hline KPK & 37,973 & 561 & 1,260 & 36,152 \\
\hline Punjab & 99,812 & 1,856 & 2,240 & 95,716 \\
\hline Sindh & 138,050 & 4,719 & 2,520 & 130,811 \\
\hline
\end{tabular}



Fig. 1 The situation of COVID-19 in Pakistan (as of October 04, 2020)

capita income per annum (Hussain et al. 2018). Pakistan is situated between longitudes $60^{\circ} \mathrm{E}-75^{\circ} \mathrm{E}$ and latitudes $24^{\circ} \mathrm{N}-$ $37^{\circ} \mathrm{N}$ (Ali 2018). Pakistan has four provinces such as Punjab,
Sind, Khyber Pakhtunkhwa, and Baluchistan; and three administrative units such as Gilgit-Baltistan, Islamabad Capital Territory, and Azad Jammu and Kashmir. Pakistan has 2.08 
billion populations, showing $2.4 \%$ annual population growth rate. Punjab is most populated province in Pakistan, with $110,012,442$ population, $205,344 \mathrm{~km}^{2}$ area, and $445.01 / \mathrm{km}^{2}$ population density. Sindh has $47,886,051$ population, $140,914 \mathrm{~km}^{2}$ area, and $392.05 / \mathrm{km}^{2}$ population density. Khyber Pakhtunkhwa has 30,523,371 population, 74,521 $\mathrm{km}^{2}$ area, and $360.93 / \mathrm{km}^{2}$ population density. Baluchistan has $12,344,408$ population, $347,190 \mathrm{~km}^{2}$ area, and $37.91 /$ $\mathrm{km}^{2}$ population density. Islamabad capital has 2,006,572 population, $906 \mathrm{~km}^{2}$ area, and $1271.38 / \mathrm{km}^{2}$ population density (Hussain et al. 2018). Pakistani climate shows regional diversity from arid to humid. Pakistan is blessed with the monsoon rainfall in summer and western systems rainfall in winter. The climate of Pakistan showed variations in the temperature (Ali 2018).

\section{Data collection}

This study used COVID-19 data (Government of Pakistan (GOP) 2020a) in the case of Pakistan from March 10, 2020, to August 25, 2020. The data of meteorological indicators like temperature $\left({ }^{\circ} \mathrm{C}\right)$ and rainfall $(\mathrm{mm})$ was obtained from the Pakistan Meteorological Department (Government of Pakistan (GOP) 2020b). The humidity (\%) data was obtained from World Weather Online (World Weather Online 2020). The infection rate shows the speed of the COVID-19 transmission, which was calculated as (Ahmadi et al. 2020):

Infection Rate $(I R)=\frac{\text { Number of Infected Persons }}{\text { Days of Infection (Outbreak) }}$

\section{Data analysis}

\section{Correlation analysis}

The non-parametric tests (Spearman's and Kendall's rank correlations) were used to investigate the association between two variables. These tests were computed on ranks and depicted a monotonic association (Hamadeh et al. 2017). Spearman's rank correlation coefficient was used to investigate the correlation between meteorological variables and COVID-19 cases and infection rate. It used a monotonic function to analyze the association between two variables. Spearman's rank correlation coefficient is estimated as (Şahin 2020):

$r_{\mathrm{s}}=1-6 \frac{\sum d_{\mathrm{i}}^{2}}{n\left(n^{2}-1\right)}$

where $n$ shows the number of alternatives, and $d_{\mathrm{i}}$ shows the gap among ranks of two parameters. The coefficient of Kendall's rank correlation $(\tau)$ was estimated as (Kocsis and Anda 2018):
$\tau=\frac{\mathrm{S}}{\mathrm{D}}$

Where $\mathrm{S}$ shows trend and $\mathrm{D}$ shows data pairs using $n$ members of dataset (Kocsis and Anda 2018):

$\mathrm{D}=\left(\begin{array}{l}\mathrm{n} \\ 2\end{array}\right)$

\section{Regression analysis}

A generalized linear model was found useful to assess the link between COVID-19 cases and different factors (Prata et al. 2020). The generalized additive model (GAM) established a univariate response variable $\mathrm{Y}$, to predictor variables xi. The exponential family of distribution was specified for $\mathrm{Y}$ like Poisson, normal, and binomial (Goswami et al. 2020). The relationship between meteorological variables and COVID19 cases was explored using GAM, to fit equations and splines. The GAM fitted for parametric and nonparametric regression and smoothing. It was used to estimate the linear and nonlinear association between meteorological factors and health indicators (Zhu and Xie 2020). An additive and semiparametric polynomial model was expressed as (Prata et al. 2020):

$$
\begin{aligned}
\log y_{\mathrm{t}}= & \beta_{0}+\beta_{1} \mathrm{x}_{\mathrm{t}}^{3}-\beta_{2} x_{\mathrm{t}}^{2}+\beta_{3} x_{\mathrm{t}}+s\left(\mathrm{AT}_{\mathrm{t}}\right)+s\left(\mathrm{RF}_{\mathrm{t}}\right) \\
& +s\left(\mathrm{HUM}_{\mathrm{t}}\right)+\varepsilon_{\mathrm{t}}
\end{aligned}
$$

where $y$ shows the COVID-19 cases in Pakistan, its provinces, and administrative units on day $t, \beta_{0}$ represents the intercept, $s(\cdot)$ shows a spline function with two degrees of freedom to control over-fitting (Liu et al. 2020; Wang et al. 2018), $\beta$ shows the parameter of $x$, and $x$ shows the days since the first outbreak, AT represents average daily temperature $\left({ }^{\circ} \mathrm{C}\right), \mathrm{RF}$ shows the average rainfall $(\mathrm{mm})$, and HUM shows the average humidity per day (\%). The explanatory variables were controlled for confounding using expression $s(\cdot)$. The smoothing spline function could control the effects of confounding factors (Ma et al. (2020). Ma et al. (2020) used GAM to explore the relationship between meteorological variables (temperature and humidity) and COVID-19 death in China. The GAM model used both linear and nonparametric trends to optimize the linear model. However, Prata et al. (2020) mentioned the statistical significance of a linear association between meteorological variables and COVID-19, which was expressed as (Prata et al. 2020):

$$
\begin{aligned}
\log y_{\mathrm{t}}= & \beta_{0}+\beta_{1} x_{\mathrm{t}}^{3}-\beta_{2} x_{\mathrm{t}}^{2}+\beta_{3} \mathrm{x}_{\mathrm{t}}+\beta_{4} \mathrm{AT}_{\mathrm{t}}+\beta_{5} \mathrm{RF}_{\mathrm{t}} \\
& +\beta_{6} \mathrm{HUM}_{\mathrm{t}}+\varepsilon_{\mathrm{t}}
\end{aligned}
$$


A dose-response function $\mathrm{f}$ connected several explanatory variables (dose $\mathrm{x}$ ), with a probability of infection (response $f(x)$ ) (Brouwer et al. 2017). The dose-response association was normally expressed graphically and showed different mathematical distributions to express a clear relationship (Sullivan et al. 2005). Mathematically, a dose-response relationship showed the expectation of potential loss as a function of different environmental indicators (Ye et al. 2020). Chuang et al. (2016) used GAM to explore the dose-response association between the daptomycin dose and mortality. In the present study, the GAM was applied to establish a dose-response function, which connected different dose variables (outbreak days, average temperature, rainfall, and humidity), with a probability of COVID-19 infection (response variable).

Li et al. (2019) used the Poisson model to explore the association between total cases and meteorological variables. Poisson regression is a commonly used classical model, which was based upon the classical assumptions. It was further assumed that the dependent variable had Poisson distribution, as the random variable showed a value $0,1,2,3, \ldots n$. It explained the distribution of $y_{i}$ or the expected value $y_{i}$ by the explanatory variables $x_{i}$, as expressed below (Cupal et al. 2015):

$\mathrm{E}\left\{\mathrm{y}_{\mathrm{i}} \mid \mathrm{x}_{\mathrm{i}}\right\}=\exp \left\{\mathrm{x}_{\mathrm{i}}^{\mathrm{T}} \beta\right\}$

The count data models assumed that the count variable $y_{i}$ for given $x_{i}$ had a Poisson distribution.

$$
\begin{gathered}
\mathrm{P}\left\{y_{\mathrm{i}}=y \mid x_{\mathrm{i}}\right\}=\exp \left\{-\lambda_{\mathrm{i}}\right\} \lambda_{\mathrm{i}}^{\mathrm{y}} / y !, y \\
=0,1,2,3, \ldots \ldots \ldots \ldots \ldots \ldots \ldots
\end{gathered}
$$

where $y$ ! shows y factorial. Substituting the appropriate functional form for $\lambda_{i}$ produced expressions for the probabilities used to construct the log-likelihood function for this model, called the Poisson regression model. The generalized Poisson regression was capable to explain the count data with any type of dispersion. It incorporated both positive and negative correlation between response variables (Consul and Famoye 1992; Famoye 2014). The generalized Poisson regression was beneficial in the presence of over-dispersion $\left(\operatorname{Var}\left(y_{i}\right)>E\left(y_{i}\right)\right)$ and under-dispersion $\left(\operatorname{Var}\left(y_{i}\right)<E\left(y_{i}\right)\right)$. According to the generalized Poisson distribution, the probability density function of $y_{i}$ was expressed as (Famoye 1993; Maxwell et al. 2018):

$$
\begin{gathered}
\mathrm{f}_{\mathrm{i}}\left(y_{i}, \mu_{i}, \alpha\right)=\left(\frac{\mu_{\mathrm{i}}}{1+\alpha \mu_{\mathrm{i}}}\right) \frac{\left(1+\alpha y_{\mathrm{i}}\right)^{\mathrm{y}_{\mathrm{i}}-1}}{\mathrm{y}_{\mathrm{i}} !} \exp \left[\frac{\mu_{i}\left(1+\alpha y_{i}\right)}{1+\alpha \mu_{i}}\right] \\
y_{\mathrm{i}}=0,1,2,, \ldots \ldots \text { and } \mu_{i}=\mu_{i}\left(x_{i}\right)=\exp \left(x_{i} \beta\right)
\end{gathered}
$$

where $x_{i}$ shows a (k-1) dimensional vector of covariates such as driving habits, demographic factors, and medication use, and $\beta$ shows (k-1) dimensional vector of regression parameters. It assumed that:

Mean : $E\left(Y_{i} \mid x+i\right)=\mu_{i}$

Variance : $\quad V\left(Y_{i} \mid x_{i}\right)=\mu_{i}\left(1+\alpha \mu_{i}\right)^{2}$

The generalization of standard Poisson regression was called generalized Poisson regression (Maxwell et al. 2018). This study also used generalized Poisson regression to assess the link between meteorological variables and COVID-19 cases. The empirical analysis was performed using R software, STATA 15, and Eviews 10.

\section{Results and discussion}

\section{The trend of COVID-19 and meteorological indicators in Pakistan}

Figures 2, 3, 4, 5, 6, 7, 8, 9, 10, and 11 show the trend of meteorological indicators (temperature, rainfall, and humidity), day-wise COVID-19 cases, and total COVID-19 cases in Pakistan from March 10, 2020, to August 25, 2020. Figure 2 shows that the day-wise trend showed a continuous increase in Pakistan up to June 13, 2020. After that, the reduction in the day-wise COVID-19 cases was reported in Pakistan. The COVID-19 cases were 482 on August 25, 2020. However, there were some fluctuations in the day-wise confirmed cases. Figure 3 shows the daywise cases in provinces and administrative areas. It was cleared that the day-wise increase was more in Punjab and Sindh provinces. It might be due to the higher population and population density in Punjab and Sindh. Figure 4 shows the trend of total COVID-19 cases in Pakistan. It showed a rapid increase in the total COVID-19 cases from March 10, 2020, to June 13, 2020. After that, COVID-19 cases were increased at a decreasing rate. Figure 5 shows total COVID-19 cases in provinces and administrative areas. It is cleared that the total COVID-19 cases were

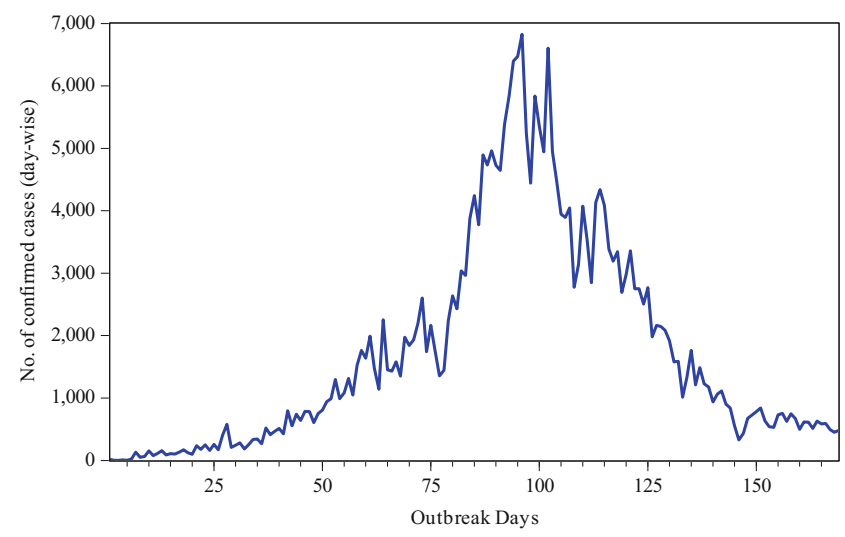

Fig. 2 No. of confirmed cases (day-wise) in Pakistan 


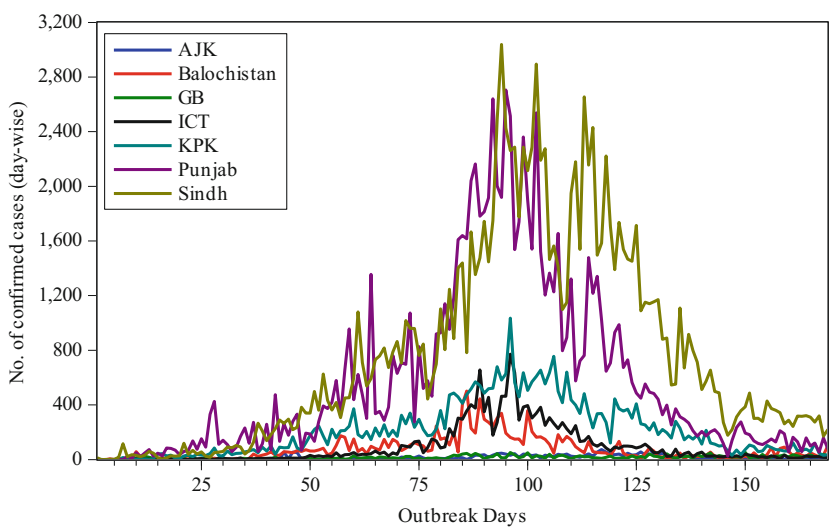

Fig. 3 No. of confirmed cases (day-wise) in provinces and administrative areas

higher in Sindh province followed by Punjab, Khyber Pakhtunkhwa, Islamabad Capital Territory, Baluchistan, Gilgit-Baltistan, and Azad Jammu and Kashmir. It was cleared that Punjab and Sindh provinces were mostly affected by the COVID-19. Figure 6 shows the trend of average temperature in Pakistan. There are fluctuations in average temperature in Pakistan. However, there was an increasing trend in average temperature from March 10, 2020, to May 27, 2020. After that, there was no significant increase in temperature, but it shows fluctuation in average temperature. Figure 7 shows the average temperature in provinces and administrative areas. The average temperature was higher in Sindh province followed by Punjab, Baluchistan, Islamabad Capital Territory, Azad Jammu and Kashmir, Khyber Pakhtunkhwa, and Gilgit-Baltistan. The average temperature also showed fluctuations in provinces and administrative units. Figure 8 shows the trend of average rainfall per day in Pakistan. There was no specific trend in the rainfall per day in Pakistan due to the presence of fluctuations between March 10, 2020, and August 25, 2020. Figure 9 shows the average rainfall per day in provinces and administrative units. Average rainfall per day also showed fluctuations in all provinces and administrative

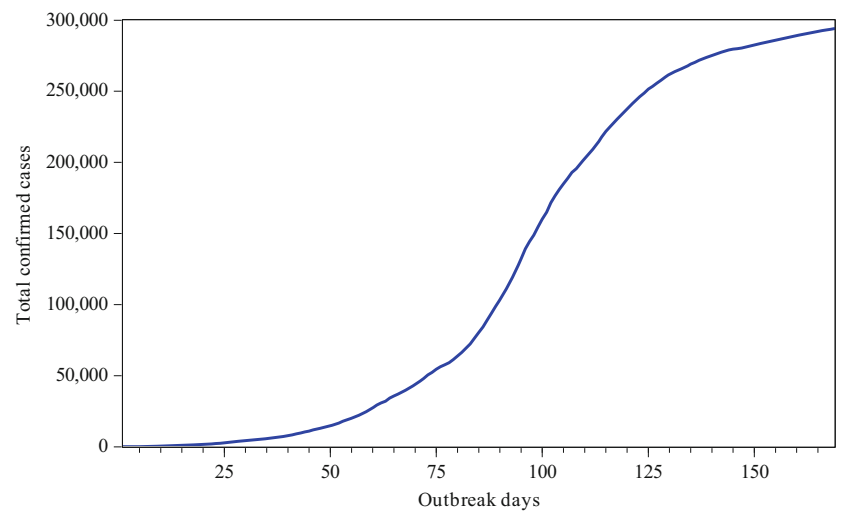

Fig. 4 Total confirmed cases in Pakistan

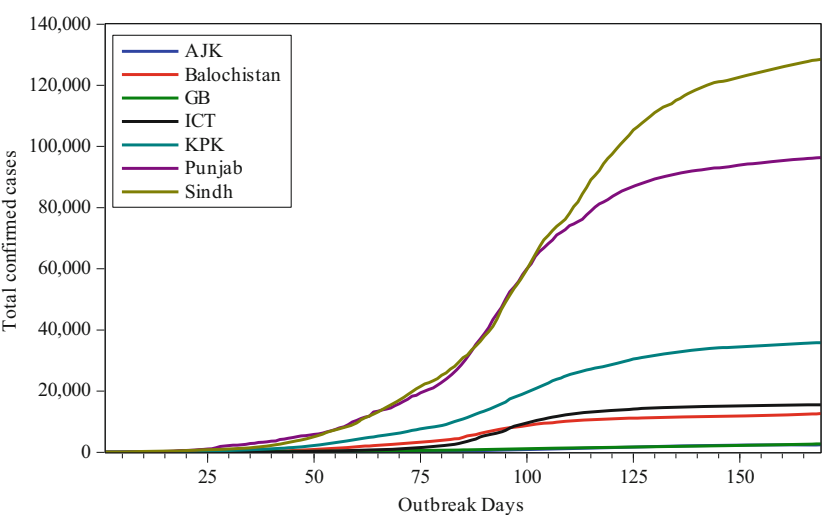

Fig. 5 Total confirmed cases in provinces and administrative areas

units. However, average rainfall per day showed upward spikes after the COVID-19 outbreak in Pakistan. The trend of humidity (Fig. 10) shows a decreasing trend from March 10, 2020, to June 17, 2020. After that, there was an increasing trend of humidity in Pakistan. Figure 11 shows the humidity in provinces and administrative units. The humidity also showed fluctuations in all provinces and administrative units between March 10, 2020, and August 25, 2020. An increasing trend of humidity was found in Sindh province. However, other provinces and administrative units showed a minor reduction in humidity up to the first week of June 2020. After that, the increasing trend of humidity was observed in provinces and administrative units. However, fluctuations in humidity were also observed in provinces and administrative units.

\section{Mean of COVID-19 and meteorological variables}

Table 1 explores the mean of meteorological indicators (temperature, rainfall, and humidity), daily COVID-19 cases, COVID-19 infection rate, and COVID-19 deaths in Pakistan, its provinces, and administrative units. The mean minimum temperature was more in Sindh followed by Punjab, Baluchistan, Islamabad Capital Territory,

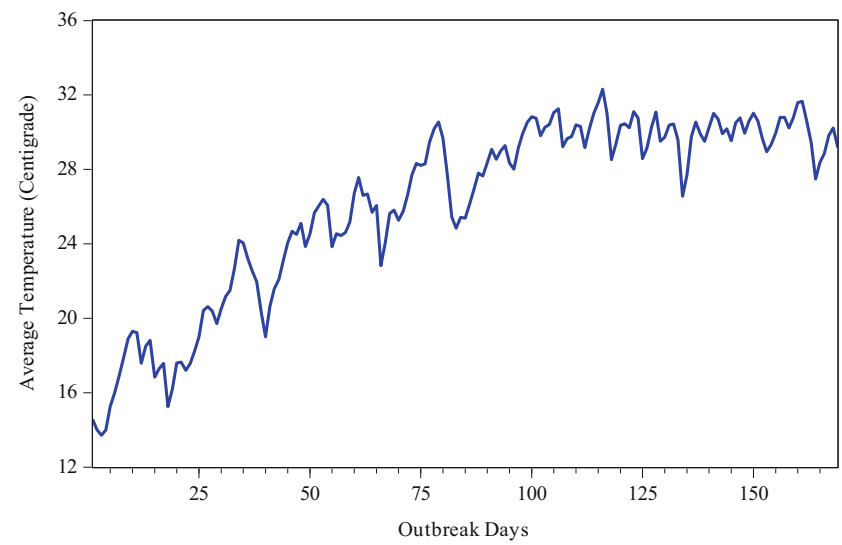

Fig. 6 The average temperature in Pakistan 


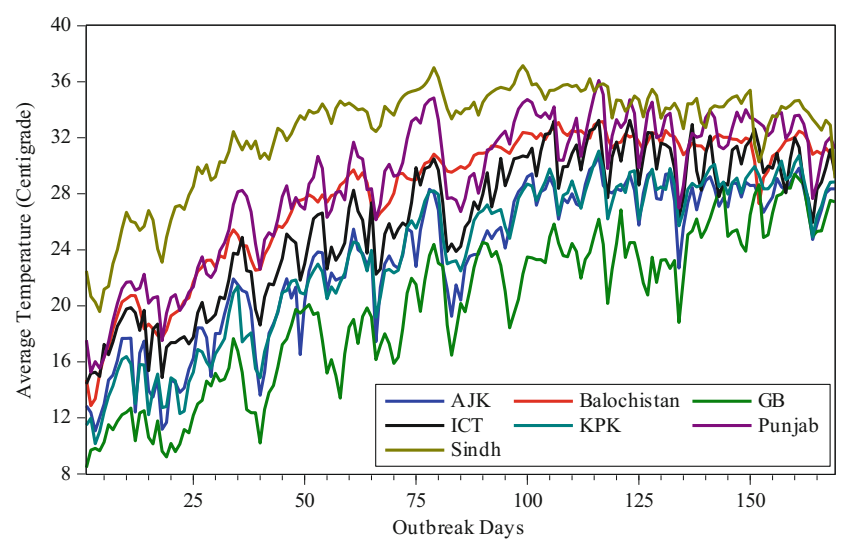

Fig. 7 The average temperature in provinces and administrative areas

Khyber Pakhtunkhwa, Azad Jammu and Kashmir, and Gilgit-Baltistan. During the first 169 days of COVID-19, the highest maximum temperature was reported in Sindh followed by Punjab, Baluchistan, Islamabad Capital Territory, Khyber Pakhtunkhwa, Azad Jammu and Kashmir, and Gilgit-Baltistan. The mean of average temperature was higher in Sindh $\left(32.52{ }^{\circ} \mathrm{C}\right)$ followed by Punjab $\left(28.90{ }^{\circ} \mathrm{C}\right)$, Baluchistan $\left(28.01{ }^{\circ} \mathrm{C}\right)$, Islamabad Capital Territory $\left(26.14{ }^{\circ} \mathrm{C}\right)$, Khyber Pakhtunkhwa $\left(23.66{ }^{\circ} \mathrm{C}\right)$, Azad Jammu and Kashmir $\left(23.47{ }^{\circ} \mathrm{C}\right)$, and Gilgit-Baltistan $\left(19.91{ }^{\circ} \mathrm{C}\right)$. The average rainfall per day was more in Islamabad Capital Territory $(4.79 \mathrm{~mm})$ followed by Azad Jammu and Kashmir $(4.35 \mathrm{~mm})$, Khyber Pakhtunkhwa $(2.81 \mathrm{~mm})$, Punjab $(2.40 \mathrm{~mm})$, Sindh $(1.02 \mathrm{~mm})$, Baluchistan $(0.69 \mathrm{~mm})$, and GilgitBaltistan $(0.51 \mathrm{~mm})$. The average rainfall in Pakistan was $2.40 \mathrm{~mm}$ per day. The average humidity was more in Sindh (65.13\%) followed by Azad Jammu and Kashmir $(56.30 \%)$, Gilgit-Baltistan (50.34\%), Islamabad Capital Territory (43.47\%), Khyber Pakhtunkhwa (39.10\%), Punjab (36.40\%), and Baluchistan $(32.29 \%)$. However, average humidity was $46.15 \%$ in Pakistan. The average per-day COVID-19 cases were 1740.21 in Pakistan. Punjab, Sindh, and Khyber Pakhtunkhwa provinces were

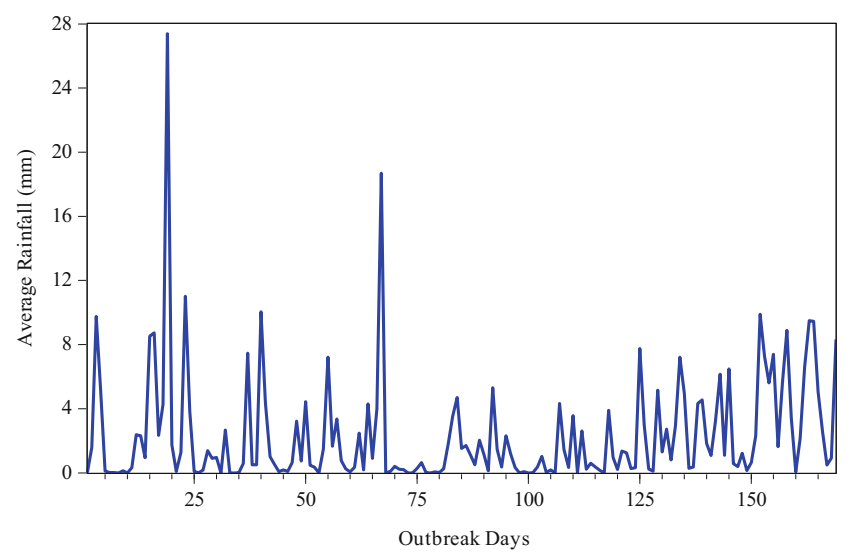

Fig. 8 Average rainfall in Pakistan

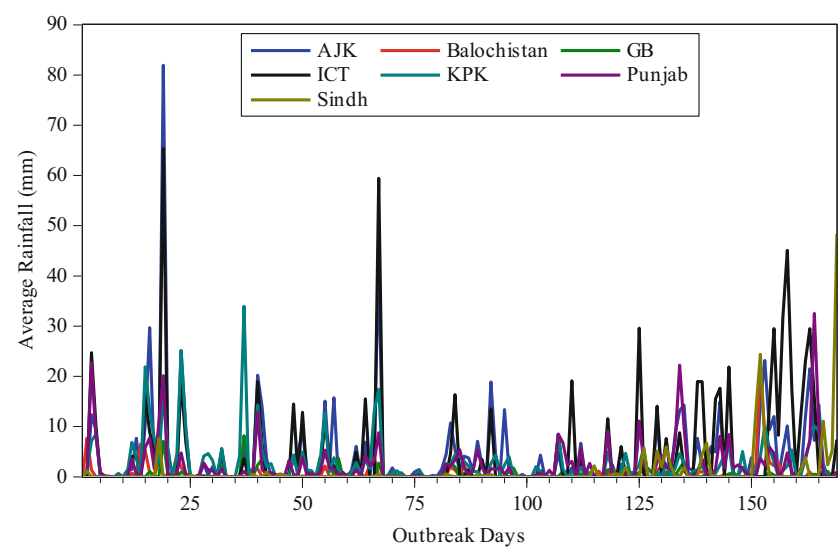

Fig. 9 Average rainfall in provinces and administrative areas

badly affected due to the COVID-19 outbreak in Pakistan. The infection rate was 1046.99 in Pakistan while it was 368.59 in Punjab, 424.74 in Sindh, 131.42 in Khyber Pakhtunkhwa, 51.39 in Baluchistan, 9.91 in GilgitBaltistan, 53.56 in Islamabad Capital Territory, and 7.38 in Azad Jammu and Kashmir. On average, 37.08 deaths per day were reported in Pakistan during this pandemic. The COVID-19 deaths were more in Sindh followed by Punjab and Khyber Pakhtunkhwa.

\section{Correlation coefficients between meteorological variables and COVID-19}

Tables 2 and 3 show the Spearman's and Kendall's rank correlation analysis. The five meteorological variables like temperature (minimum, maximum, average), rainfall, and humidity were used in correlation analysis with total COVID-19 cases (Table 2) and COVID-19 infection rate (Table 3). Both Spearman's and Kendall's rank correlation shows the same direction between selected variables. Tosepu et al. (2020) used weather-related indicators in the case of Jakarta. But this study used these variables for the country level (Pakistan) as well as provincial level (Punjab, Sindh, Baluchistan, Khyber



Fig. 10 Humidity in Pakistan 


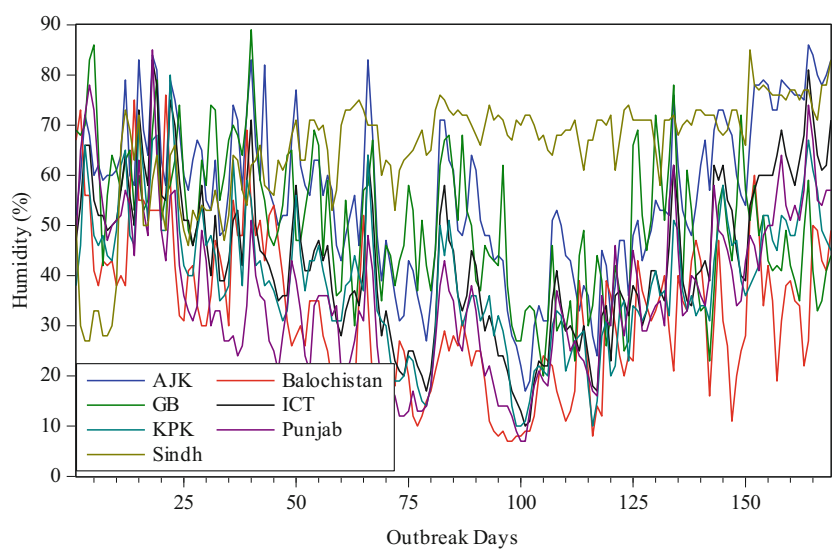

Fig. 11 Humidity in provinces and administrative areas

Pakhtunkhwa, Islamabad Capital Territory, GilgitBaltistan, and Azad Jammu and Kashmir). The results showed that temperature (minimum, maximum, and average) has highest correlation coefficient. Therefore, average temperature is closely linked with the COVID-19 cases. It implies that the COVID-19 cases increased in Pakistan due to an increase in average temperature, which was in line with the results of Tosepu et al. (2020) in the case of Jakarta, Indonesia. A positive correlation was also observed between total cases and average temperature in New York, USA, which was badly affected by COVID-19 (Bashir et al. 2020). Temperature is an environmental factor behind COVID19 spread in China (Shi et al. 2020). Contrarily, Şahin (2020) reported an increase in COVID-19 cases due to a reduction in average temperature in Turkey. Sobral et al. (2020) also reported a reduction in infections due to an increase in temperature. In past studies, Bi et al. (2007) also reported an inverse correlation between SARS cases and temperature in Beijing and Hong Kong. The diversified results between temperature and COVID-19 cases were due to the fact that the impact of temperature on human health may vary between different regions or countries (Hajat and Kosatky 2010; Sobral et al. (2020). The literature highlighted that influenza and SARS-CoV viruses survived only under specific climatic conditions and their transmission rate was sensitive to increasing temperature (Chan et al. 2011; Jaakkola et al. 2014). Second, correlation between average rainfall and COVID-19 cases was negative and significant in Pakistan, which implies the reduction in COVID-19 cases due to rainfall in Pakistan. However, those findings were not in line with findings of Tosepu et al. (2020) in the case of Jakarta, Indonesia. It seems that weather and COVID-19 behavior was different in Pakistan and Indonesia. Another study (Bashir et al. 2020) showed an insignificant correlation between rainfall and COVID-19 cases in New York, USA. Contrarily to Tosepu et al. (2020), correlation between humidity and the total COVID-19 cases was negative in Pakistan, which implies the reduction in COVID-19 cases due to an increase in the level of humidity in Pakistan. The reduction in COVID-19 cases due to a rise in the level of humidity was also reported in Turkey (Şahin 2020). It means that Pakistan and Turkey showed similarities with respect to COVID-19 and humidity. It was also noted that the absolute value of negative correlation between humidity and COVID-19 cases was higher in Pakistan (0.742) as compared to Turkey (0.317) (Șahin 2020). Moreover, Ma et al. (2020) also indicated a reduction in COVID-19 cases due to higher humidity in China. Chan et al. (2011) pointed out that higher relative humidity eliminated the virus viability, which supported the findings of the present research. Along with environmental factors, population ( $\mathrm{Zu}$ et al. 2020), population density, medical care (Wang et al. 2020b), people's endurance, social distancing, and health facilities (Bashir et al. 2020) were also possible reasons behind spread or control of COVID-19. A higher correlation coefficient was observed between temperature (minimum, maximum, and

Table 1 Mean of COVID-19 and meteorological variables

\begin{tabular}{|c|c|c|c|c|c|c|c|c|}
\hline Indicators & Punjab & Sindh & KPK & Baluchistan & GB & ICT & AJK & Pakistan \\
\hline \multicolumn{9}{|l|}{ Meteorological variables } \\
\hline Minimum temperature $\left({ }^{\circ} \mathrm{C}\right)$ & 22.60 & 25.77 & 16.89 & 21.29 & 13.10 & 19.59 & 16.79 & 19.43 \\
\hline Maximum temperature $\left({ }^{\circ} \mathrm{C}\right)$ & 35.19 & 39.27 & 30.44 & 34.74 & 26.72 & 32.69 & 30.16 & 32.74 \\
\hline Average temperature $\left({ }^{\circ} \mathrm{C}\right)$ & 28.90 & 32.52 & 23.66 & 28.01 & 19.91 & 26.14 & 23.47 & 26.09 \\
\hline Rainfall per day (mm) & 2.40 & 1.02 & 2.81 & 0.69 & 0.51 & 4.79 & 4.35 & 2.40 \\
\hline Humidity per day (\%) & 36.40 & 65.13 & 39.10 & 32.29 & 50.34 & 43.47 & 56.30 & 46.15 \\
\hline \multicolumn{9}{|l|}{ COVID-19 indicators } \\
\hline COVID-19 cases per day & 570.27 & 760.51 & 212.02 & 74.91 & 16.21 & 91.98 & 14.31 & 1740.21 \\
\hline Infection rate & 368.59 & 424.74 & 131.42 & 51.39 & 9.91 & 53.56 & 7.38 & 1046.99 \\
\hline COVID-19 deaths per day & 12.97 & 14.12 & 7.38 & 0.83 & 0.38 & 1.04 & 0.36 & 37.08 \\
\hline
\end{tabular}


Table 2 Correlation between meteorological variables and total COVID-19 cases

\begin{tabular}{|c|c|c|c|c|c|c|c|c|}
\hline Meteorological variables & Punjab & Sindh & KPK & Baluchistan & GB & $\mathrm{ICT}$ & AJK & Pakistan \\
\hline \multicolumn{9}{|c|}{ Spearman's rank correlation coefficient } \\
\hline Minimum temperature $\left({ }^{\circ} \mathrm{C}\right)$ & $0.363 *$ & $0.713^{*}$ & $0.442 *$ & $0.334 *$ & $0.583^{*}$ & $0.555^{*}$ & $0.628^{*}$ & $0.490 *$ \\
\hline Maximum temperature $\left({ }^{\circ} \mathrm{C}\right)$ & $0.626^{*}$ & $0.716^{*}$ & $0.531 *$ & $0.488^{*}$ & $0.541^{*}$ & $0.687^{*}$ & $0.640^{*}$ & $0.649 *$ \\
\hline Average temperature $\left({ }^{\circ} \mathrm{C}\right)$ & $0.511^{*}$ & $0.819 *$ & $0.477^{*}$ & $0.422 *$ & $0.570^{*}$ & $0.644^{*}$ & $0.650^{*}$ & $0.584 *$ \\
\hline Rainfall per day (mm) & -0.065 & 0.013 & $-0.148 * * *$ & $-0.229 *$ & $0.142 * * *$ & -0.124 & -0.074 & $-0.144 * * *$ \\
\hline Humidity per day (\%) & $-0.721 *$ & $0.391 *$ & $-0.698^{*}$ & $-0.621 *$ & $-0.355^{*}$ & $-0.701 *$ & $-0.490^{*}$ & $-0.742 *$ \\
\hline \multicolumn{9}{|c|}{ Kendall's rank correlation coefficient } \\
\hline Minimum temperature $\left({ }^{\circ} \mathrm{C}\right)$ & $0.255^{*}$ & $0.549 *$ & $0.326^{*}$ & $0.236^{*}$ & $0.402 *$ & $0.383^{*}$ & $0.431 *$ & $0.358 *$ \\
\hline Maximum temperature $\left({ }^{\circ} \mathrm{C}\right)$ & $0.451^{*}$ & $0.530 *$ & $0.373 *$ & $0.342 *$ & $0.375 *$ & $0.504 *$ & $0.446 *$ & $0.476^{*}$ \\
\hline Average temperature $\left({ }^{\circ} \mathrm{C}\right)$ & $0.365^{*}$ & $0.638^{*}$ & $0.340 *$ & $0.299 *$ & $0.396^{*}$ & $0.456^{*}$ & $0.455^{*}$ & $0.430 *$ \\
\hline Rainfall per day (mm) & -0.045 & 0.001 & $-0.106^{* *}$ & $-0.142 *$ & $0.090 * * *$ & -0.076 & -0.052 & $-0.102 * *$ \\
\hline Humidity per day (\%) & $-0.519 *$ & $0.254^{*}$ & $-0.493 *$ & $-0.431 *$ & $-0.240^{*}$ & $-0.496^{*}$ & $-0.306^{*}$ & $-0.533 *$ \\
\hline
\end{tabular}

average) and COVID-19 cases for all provinces and administrative units (Punjab, Sindh, Baluchistan, Khyber Pakhtunkhwa, Islamabad Capital Territory, GilgitBaltistan, and Azad Jammu and Kashmir). The correlation between rainfall and COVID-19 cases was significant and negative in the case of Khyber Pakhtunkhwa and Baluchistan. It implies that the increase in rainfall was linked with a reduction in COVID-19 cases. A positive correlation was reported between rainfall and COVID-19 cases in Gilgit-Baltistan. In general, humidity had a negative correlation with COVID-19 cases in Punjab, Baluchistan, Khyber Pakhtunkhwa, Islamabad Capital Territory, Gilgit-Baltistan, and Azad Jammu and Kashmir. However, Sindh province showed different behavior due to a positive correlation between humidity and COVID-19 cases. To control the COVID-19, it is required to reduce the infection. The results (Table 3) showed that temperature (minimum, maximum, and average) has highest correlation coefficient. Therefore, average temperature was linked with the infection rate. It implies that the COVID-19 infection increased due to an increase in average temperature. Second, correlation between average rainfall and the COVID-19 infection rate was negative in Pakistan. A negative correlation was observed between humidity and COVID-19 infection rate. This study also explored the correlation between meteorological indicators and the COVID-19 infection rate in the case of provinces. The positive correlation coefficient was observed between temperature (minimum, maximum, and average) and COVID-19 infection for all provinces and administrative units. The correlation between rainfall and the COVID-19 infection rate was significant in Sindh and Azad Jammu and Kashmir. In general, humidity had a negative correlation with COVID-19 cases

Table 3 Correlation between meteorological variables and COVID-19 infection rate

\begin{tabular}{|c|c|c|c|c|c|c|c|c|}
\hline Meteorological variables & Punjab & Sindh & KPK & Baluchistan & GB & ICT & AJK & Pakistan \\
\hline \multicolumn{9}{|c|}{ Spearman's rank correlation coefficient } \\
\hline Minimum temperature $\left({ }^{\circ} \mathrm{C}\right)$ & $0.886^{*}$ & $0.861 *$ & $0.905^{*}$ & $0.922 *$ & $0.907 *$ & $0.887^{*}$ & $0.926^{*}$ & $0.916^{*}$ \\
\hline Maximum temperature $\left({ }^{\circ} \mathrm{C}\right)$ & $0.695^{*}$ & $0.291 *$ & $0.845^{*}$ & $0.903 *$ & $0.841 *$ & $0.793 *$ & $0.761 *$ & $0.796^{*}$ \\
\hline Average temperature $\left({ }^{\circ} \mathrm{C}\right)$ & $0.812^{*}$ & $0.604 *$ & $0.896^{*}$ & $0.938^{*}$ & $0.894 *$ & $0.893 *$ & $0.862 *$ & $0.879 *$ \\
\hline Rainfall per day (mm) & 0.099 & $0.362 *$ & -0.064 & -0.126 & 0.113 & 0.033 & $0.127 * * *$ & $0.147 * * *$ \\
\hline Humidity per day (\%) & $-0.218 *$ & $0.642 *$ & $-0.390 *$ & $-0.510 *$ & $-0.458 *$ & $-0.392 *$ & -0.094 & $-0.283^{*}$ \\
\hline \multicolumn{9}{|c|}{ Kendall's rank correlation coefficient } \\
\hline Minimum temperature $\left({ }^{\circ} \mathrm{C}\right)$ & $0.715^{*}$ & $0.712 *$ & $0.743 *$ & $0.762 *$ & $0.728 *$ & $0.708^{*}$ & $0.767 *$ & $0.766^{*}$ \\
\hline Maximum temperature $\left({ }^{\circ} \mathrm{C}\right)$ & $0.516^{*}$ & $0.204 *$ & $0.556^{*}$ & $0.724 *$ & $0.638^{*}$ & $0.603 *$ & $0.551 *$ & $0.605^{*}$ \\
\hline Average temperature $\left({ }^{\circ} \mathrm{C}\right)$ & $0.634^{*}$ & $0.456^{*}$ & $0.728^{*}$ & $0.789^{*}$ & $0.704 *$ & $0.718^{*}$ & $0.671^{*}$ & $0.711^{*}$ \\
\hline Rainfall per day (mm) & 0.071 & $0.221 *$ & -0.046 & -0.080 & 0.072 & 0.019 & $0.086^{* * *}$ & $0.096 * * *$ \\
\hline Humidity per day (\%) & $-0.177 *$ & $0.460 *$ & $-0.270^{*}$ & $-0.346^{*}$ & $-0.316^{*}$ & $-0.297 *$ & $-0.093 * * *$ & $-0.210^{*}$ \\
\hline
\end{tabular}


in all provinces, excluding Sindh. In Sindh province, there was a positive correlation between humidity and COVID-19 infection rate.

\section{Dose-response relationship using generalized additive model (GAM)}

The GAM explored the association between meteorological variables (temperature, rainfall, and humidity) and the COVID-19 cases in Pakistan, its provinces, and administrative units. Figure 12 explains the dose-response link between average temperature and COVID-19 cases using the GAM. Initially, there was a direct association between temperature and COVID-19 cases, but the curve showed a flatter shape when average temperature lies between 25 and $30{ }^{\circ} \mathrm{C}$. The rise in the COVID-19 cases was also observed when average temperature was more than $30{ }^{\circ} \mathrm{C}$. The temperature was positively linked with the COVID-19 cases in Jakarta, Indonesia (Tosepu et al. 2020), and New York, USA (Bashir et al. 2020). In Punjab, the COVID-19-temperature curve showed a positive slope initially, but it was flattered when average temperature was more than $23{ }^{\circ} \mathrm{C}$. There was an inverse link between COVID-19 and temperature in GilgitBaltistan, and Azad Jammu and Kashmir. Temperature and the COVID-19 cases were positively associated in Sindh and Baluchistan. In Khyber Pakhtunkhwa and Islamabad Capital Territory, the COVID-19 cases increased when the temperature was low, but there was a reduction in the COVID-19 cases when the temperature was higher. Figure 13 explains the dose-response link between rainfall and COVID-19 cases per day, showed an increase in COVID-19 cases due to rainfall initially, but the curve was flattered when the rainfall was more than $20 \mathrm{~mm}$ per day. An insignificant association between rainfall and COVID-19 cases was reported in Jakarta, Indonesia (Tosepu et al. 2020) and New York, USA (Bashir et al. 2020). The dose-response curve between COVID-19 and rainfall was positively sloped in Sindh, Baluchistan, and Khyber Pakhtunkhwa, but it was not much steeper. The curve between COVID-19 cases and rainfall seemed like a flatter curve in Islamabad Capital Territory, Gilgit-Baltistan, and Azad Jammu and Kashmir. Figure 14 explains the presence of an inverse dose-response curve between humidity and COVID-19 cases in Pakistan. The curve was steeper when humidity was more than $70 \%$. The inverse relationship between COVID-19 cases and humidity was also reported in Turkey (Șahin 2020) and China (Ma et al. 2020) because higher relative humidity eliminated the virus viability (Chan et al. 2011). The dose-response curve showed a reduction in COVID-19 cases due to a rise in humidity in Islamabad Capital Territory, Gilgit-Baltistan, and Azad
Jammu and Kashmir. The curve was downward sloped between COVID-19 and humidity in Punjab, Baluchistan, and Khyber Pakhtunkhwa, but it showed a positive trend in the presence of a higher level of humidity.

\section{Generalized Poisson regression analysis}

Table 4 shows the impact of average temperature, rainfall per day, and humidity using time-series generalized Poisson regression in Pakistan, its provinces, and administrative units. Yuan et al. (2006) also used regression analysis to reveal the impact of temperature, wind speed, and relative humidity on SARS transmission. Temperature and humidity were significant factors in the seasonal spread of coronaviruses (Sajadi et al. 2020). Results showed that the increase in the expected log count of COVID-19 cases was 0.024 times for a $1{ }^{\circ} \mathrm{C}$ rise in average temperature in Pakistan. It implies that the increase in temperature was favorable to control the COVID-19 in Pakistan. The regression analysis of provincial and administrative units showed that the increase in expected log count of COVID-19 cases was 0.086 times in Sindh, 0.095 times in Khyber Pakhtunkhwa, and 0.156 times in Baluchistan for $1{ }^{\circ} \mathrm{C}$ rise in average temperature. The rise in the COVID-19 cases due to an increase in average temperature was also reported in Jakarta, Indonesia (Tosepu et al. 2020), and New York, USA (Bashir et al. 2020). Xie and Zhu (2020) also considered that temperature was a factor in COVID-19 transmission. Wu et al. (2020) described that the increase in new cases was $3.08 \%$ for a $1{ }^{\circ} \mathrm{C}$ rise in temperature. However, coefficient of average temperature was insignificant in Punjab, Azad Jammu and Kashmir, Islamabad Capital Territory, and Gilgit-Baltistan. The impact of rainfall on COVID-19 cases was insignificant in Pakistan. It implies that the increase in rainfall per day was not a significant factor behind the COVID-19 transmission in Pakistan. The increase in expected log count of COVID-19 cases was 0.019 times in Punjab and 0.020 times in Khyber Pakhtunkhwa for 1$\mathrm{mm}$ increase in rainfall per day. However, coefficient of rainfall was insignificant in Sindh, Baluchistan, Azad Jammu and Kashmir, Islamabad Capital Territory, and Gilgit-Baltistan. On the other hand, a reduction in the expected log count of COVID-19 cases was 0.008 times for a $1 \%$ increase in humidity per day in Pakistan. It implies that the increase in humidity was beneficial to stop COVID-19 transmission in Pakistan. The provincial and administrative units also showed that the reduction in expected log count of total COVID-19 cases was 0.015 times in Punjab, 0.018 in Islamabad Capital Territory, and 0.027 times in Azad Jammu and Kashmir for $1 \%$ increase in humidity. However, an insignificant link between COVID-19 cases 
Fig. 12 The dose-response curves between average temperature and COVID-19 cases
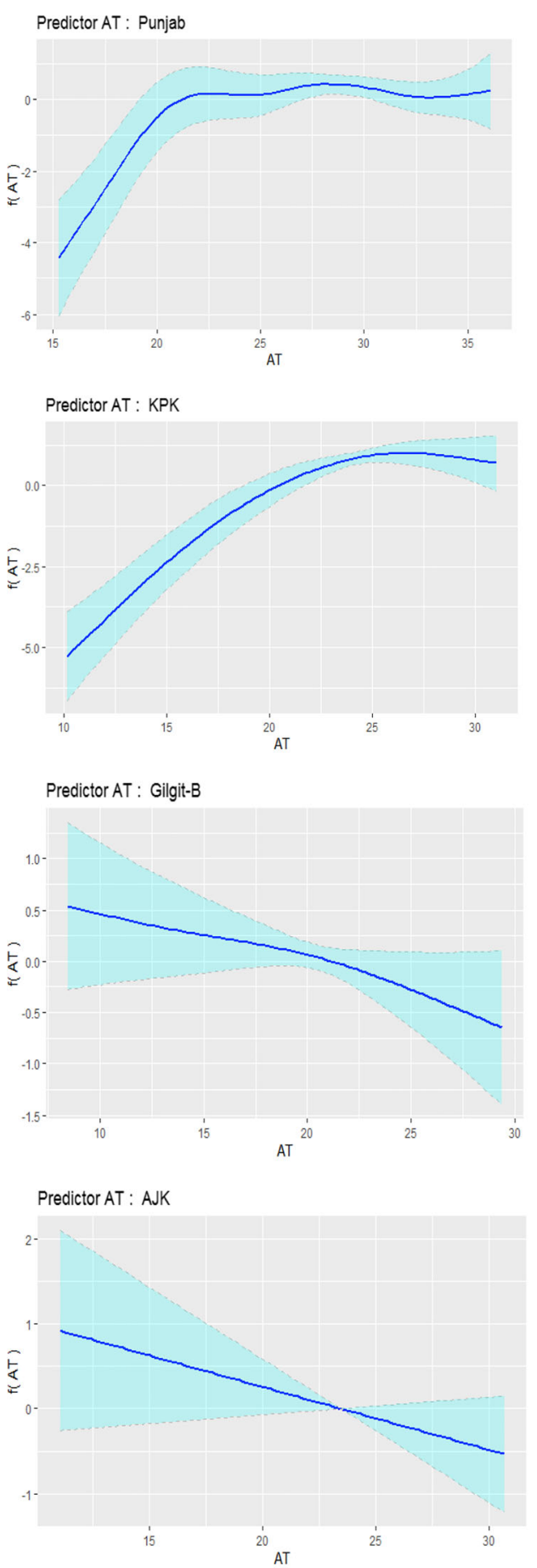
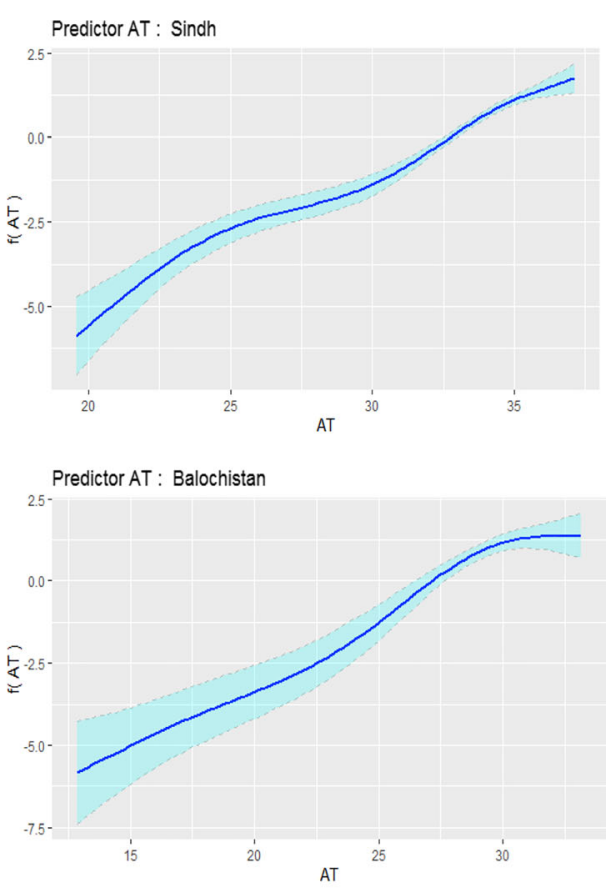

Predictor AT : Islamabad-ICT
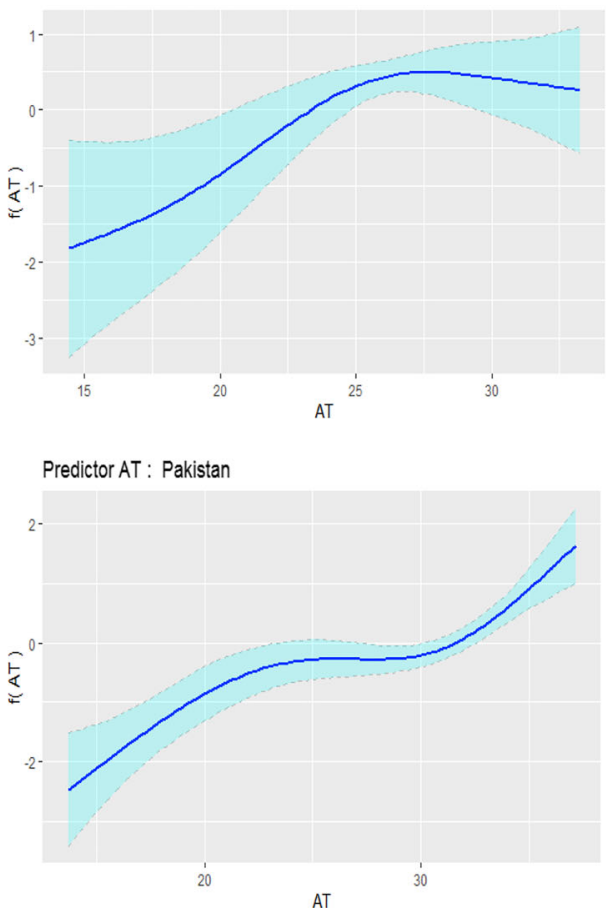

and humidity was observed in Sindh, Baluchistan, Khyber Pakhtunkhwa, and Gilgit-Baltistan. Wu et al. (2020) described $0.85 \%$ reduction in COVID-19 cases for a $1 \%$ increase in relative humidity. Chan et al. (2011) pointed out that the higher relative humidity eliminated the virus viability, which supported the empirical results. However, some other meteorological indicators (air quality and wind speed) could also affect the transmission of infectious diseases (Chen et al. 2020).

\section{Conclusions}

Public health and the global economy faced huge problems due to COVID-19. This study was designed to investigate the impact of meteorological indicators (temperature, rainfall, and humidity) on total COVID-19 cases and COVID-19 infection rate in Pakistan from March 10, 2020, to August 25, 2020. The correlation analysis implies that the COVID-19 cases increased due 
Fig. 13 The dose-response curves between rainfall and COVID-19 cases
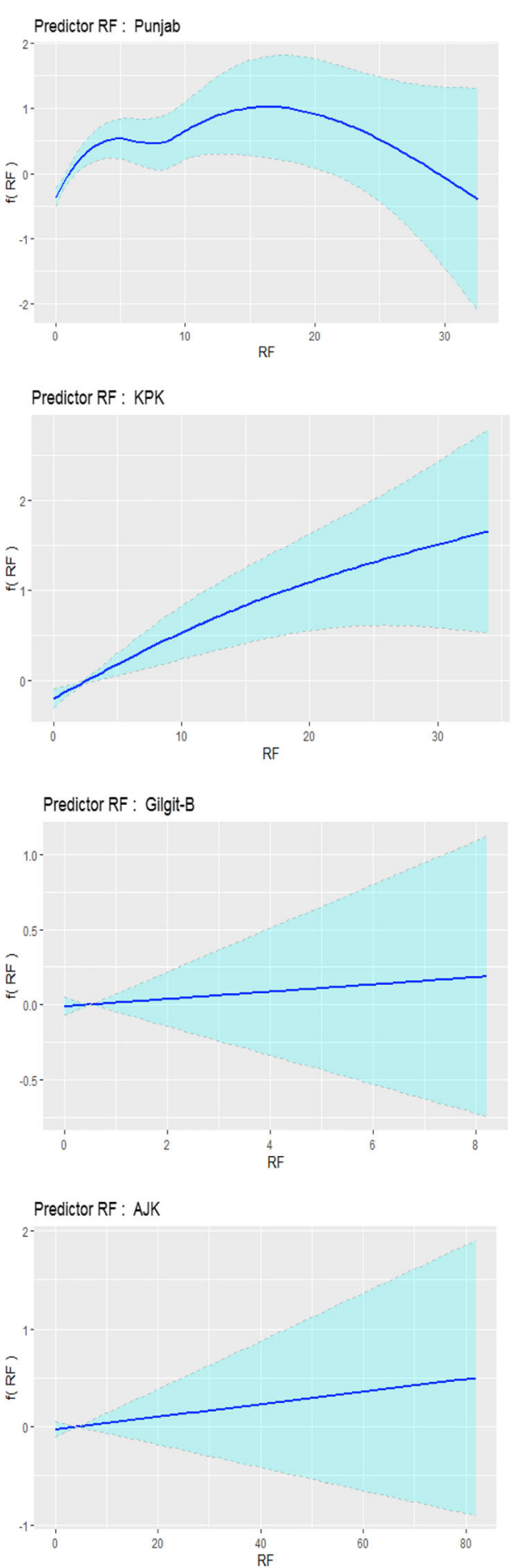
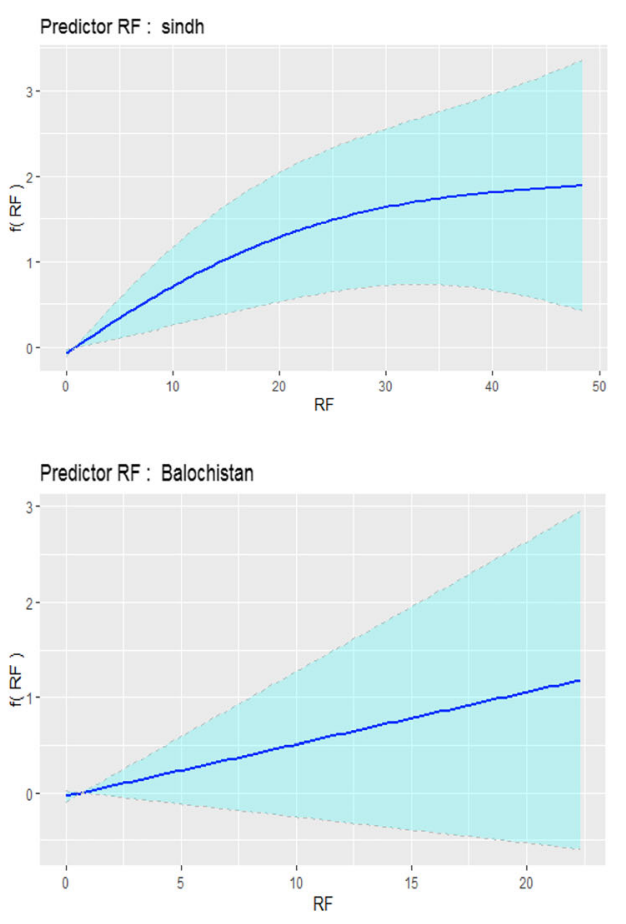

Predictor RF : Islamabad-ICT

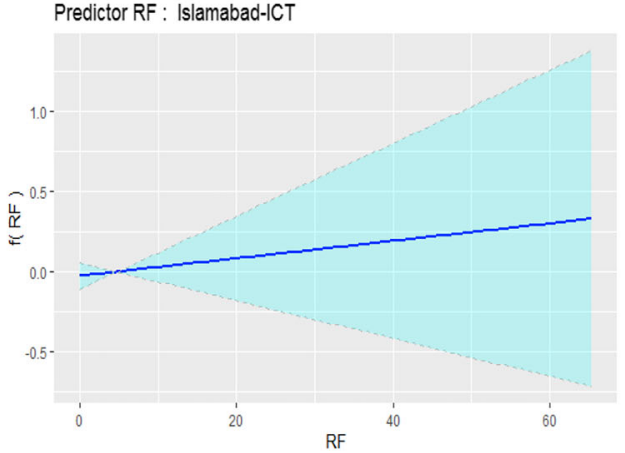

Predictor RF : Pakistan

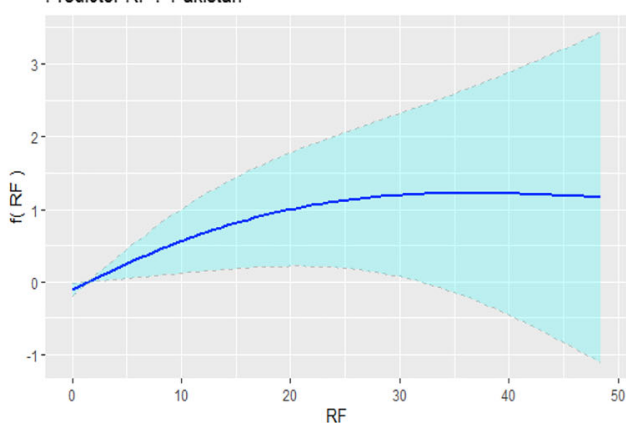

to a rise in average temperature in Pakistan, its provinces, and administrative units. The dose-response relationship showed a direct association between temperature and COVID-19 cases but the curve was flattered when average temperature lies between 25 and $30{ }^{\circ} \mathrm{C}$ in Pakistan. The increase in COVID-19 cases was also observed when average temperature was more than $30{ }^{\circ} \mathrm{C}$ in Pakistan. The results of generalized Poisson regression showed that the increase in the expected $\log$ count of COVID-19 cases was 0.024 times for a $1{ }^{\circ} \mathrm{C}$ rise in average temperature in Pakistan. Second, correlation between average rainfall and COVID-19 cases was negative in Pakistan. The dose-response curve showed an increase in COVID-19 cases due to rainfall initially but the curve was flattered when the rainfall was more than $20 \mathrm{~mm}$ per day. Third, correlation between humidity and the total 
Fig. 14 The dose-response curves between humidity and COVID19 cases
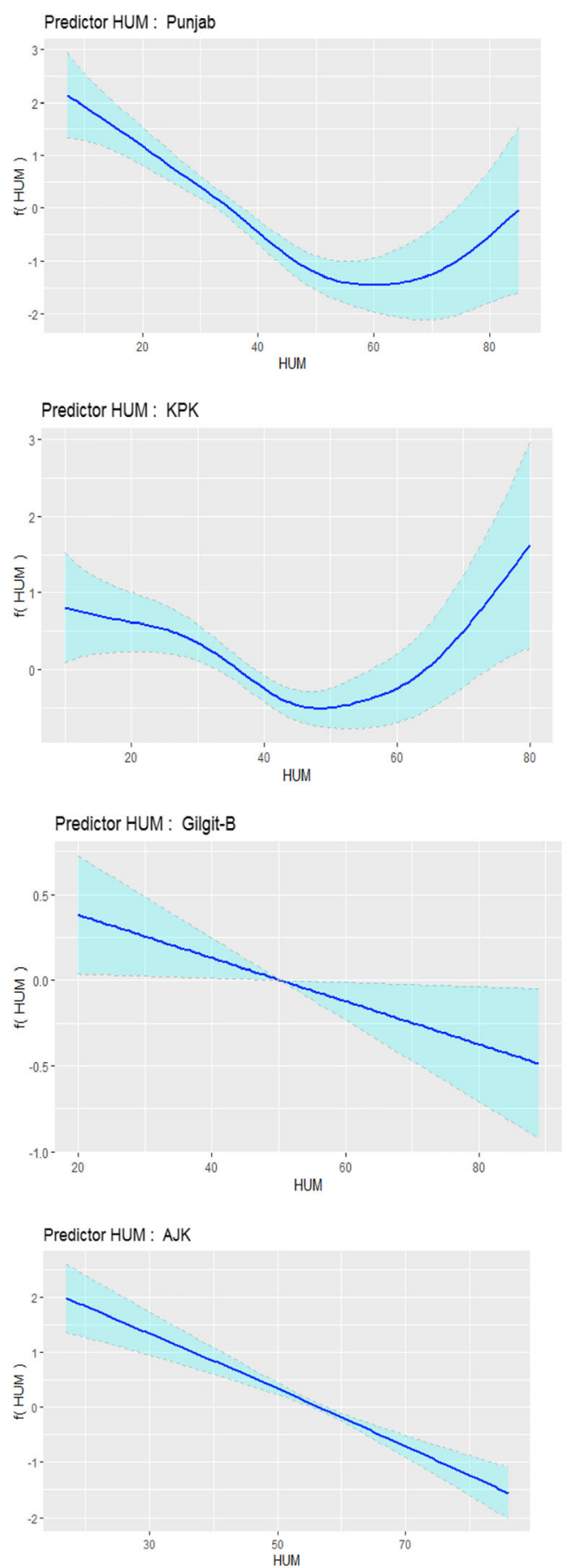
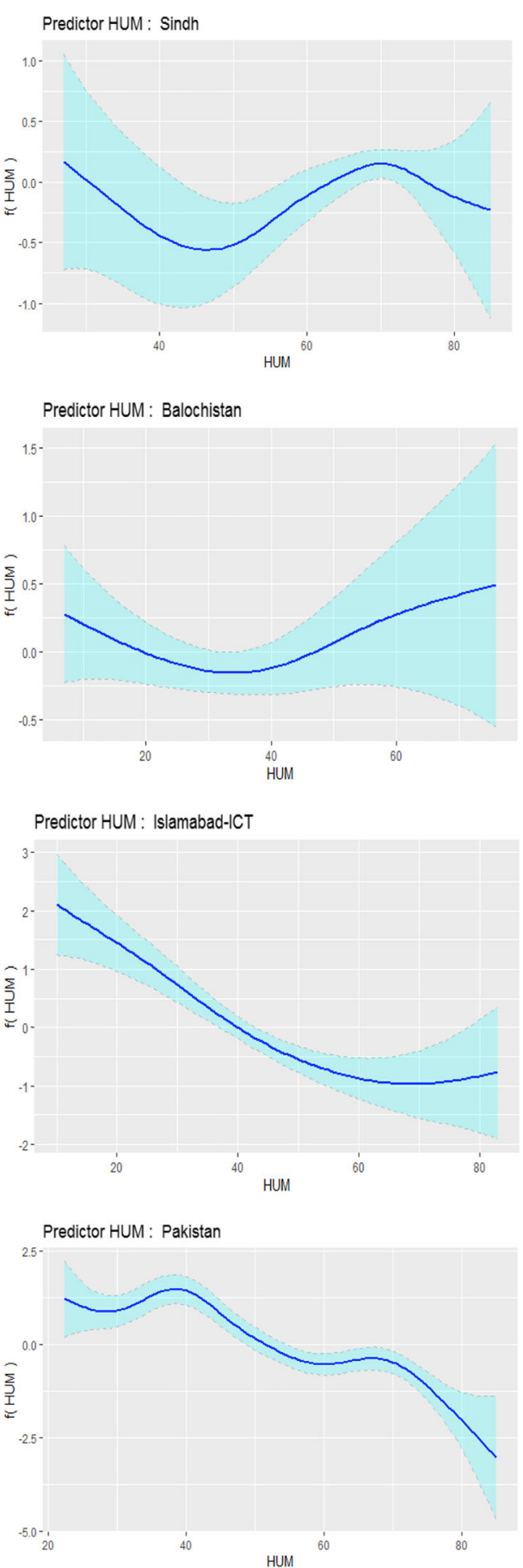

COVID-19 cases implies the reduction in COVID-19 cases due to an increase in humidity in Pakistan. The dose-response curve between humidity and COVID-19 cases showed the presence of an inverse relationship between humidity and COVID-19 cases in Pakistan. The downward slope curve becomes steeper when humidity was more than $70 \%$. The reduction in the expected $\log$ count of COVID-19 cases was 0.008 times for a $1 \%$ increase in humidity in Pakistan. It implies that the increase in humidity was beneficial to stop the COVID19 transmission. This study also had some limitations like (a) total COVID-19 cases also included those Pakistani citizens, which were affected abroad and moved to Pakistan with COVID-19 symptoms, (b) it is also important to include some other factors like virus resistance, population mobility, and immunity, (c) the spread of COVID-19 also depends upon some precautionary measures such as hand wash habits, social 
Table 4 Generalized Poisson regression analysis

\begin{tabular}{|c|c|c|c|c|}
\hline Meteorological indicators & Coefficient & Std. Err. & $z$ & Probability \\
\hline \multicolumn{5}{|l|}{ Pakistan } \\
\hline Constant & $1.376^{*}$ & 0.152 & 9.043 & 0.000 \\
\hline Days & $0.002 *$ & 0.001 & 3.198 & 0.001 \\
\hline Average temperature $\left({ }^{\circ} \mathrm{C}\right)$ & $0.024 *$ & 0.006 & 3.546 & 0.000 \\
\hline Rainfall per day (mm) & 0.003 & 0.006 & 0.455 & 0.649 \\
\hline Humidity per day (\%) & $-0.008^{*}$ & 0.002 & -4.470 & 0.000 \\
\hline \multicolumn{5}{|l|}{ Punjab Province } \\
\hline Constant & $1.609^{*}$ & 0.775 & 2.077 & $0.038 * *$ \\
\hline Days & $0.001 *$ & 0.002 & 0.609 & 0.542 \\
\hline Average temperature $\left({ }^{\circ} \mathrm{C}\right)$ & 0.015 & 0.027 & 0.541 & 0.589 \\
\hline Rainfall per day (mm) & $0.019 * *$ & 0.009 & 1.980 & 0.048 \\
\hline Humidity per day (\%) & $-0.015^{*}$ & 0.005 & -2.830 & 0.005 \\
\hline \multicolumn{5}{|l|}{ Sindh Province } \\
\hline Constant & $-1.402 *$ & 0.462 & -3.035 & 0.000 \\
\hline Days & -0.001 & 0.001 & -0.790 & 0.430 \\
\hline Average temperature $\left({ }^{\circ} \mathrm{C}\right)$ & $0.086^{*}$ & 0.015 & 5.579 & 0.000 \\
\hline Rainfall per day (mm) & 0.007 & 0.008 & 0.821 & 0.412 \\
\hline Humidity per day (\%) & 0.006 & 0.005 & 1.163 & 0.245 \\
\hline \multicolumn{5}{|l|}{ Baluchistan Province } \\
\hline Constant & $-2.547^{*}$ & 0.785 & -3.244 & 0.001 \\
\hline Days & $-0.009^{*}$ & 0.002 & -3.912 & 0.000 \\
\hline Average temperature $\left({ }^{\circ} \mathrm{C}\right)$ & $0.156^{*}$ & 0.029 & 5.366 & 0.000 \\
\hline Rainfall per day (mm) & 0.036 & 0.023 & 1.581 & 0.114 \\
\hline Humidity per day (\%) & 0.002 & 0.005 & 0.411 & 0.681 \\
\hline \multicolumn{5}{|c|}{ Khyber Pakhtunkhwa Province } \\
\hline Constant & -0.268 & 0.649 & -0.413 & 0.680 \\
\hline Days & $-0.006^{* *}$ & 0.003 & -2.050 & 0.040 \\
\hline Average temperature $\left({ }^{\circ} \mathrm{C}\right)$ & $0.095^{*}$ & 0.029 & 3.257 & 0.001 \\
\hline Rainfall per day (mm) & $0.020 * *$ & 0.009 & 2.219 & 0.027 \\
\hline Humidity per day (\%) & -0.001 & 0.005 & -0.262 & 0.793 \\
\hline \multicolumn{5}{|l|}{ Gilgit-Baltistan } \\
\hline Constant & 0.782 & 0.515 & 1.517 & 0.129 \\
\hline Days & $0.007 * *$ & 0.003 & 2.333 & 0.020 \\
\hline Average temperature $\left({ }^{\circ} \mathrm{C}\right)$ & -0.013 & 0.029 & -0.441 & 0.659 \\
\hline Rainfall per day (mm) & 0.026 & 0.053 & 0.485 & 0.628 \\
\hline Humidity per day (\%) & -0.006 & 0.005 & -1.352 & 0.176 \\
\hline \multicolumn{5}{|l|}{ Islamabad Capital Territory } \\
\hline Constant & 0.739 & 0.785 & 0.942 & 0.346 \\
\hline Days & 0.003 & 0.003 & 1.038 & 0.299 \\
\hline Average temperature $\left({ }^{\circ} \mathrm{C}\right)$ & 0.033 & 0.031 & 1.065 & 0.287 \\
\hline Rainfall per day (mm) & 0.004 & 0.005 & 0.799 & 0.424 \\
\hline Humidity per day (\%) & $-0.018^{*}$ & 0.005 & -3.526 & 0.000 \\
\hline \multicolumn{5}{|l|}{ Azad Jammu and Kashmir } \\
\hline Constant & 0.960 & 1.054 & 0.911 & 0.363 \\
\hline
\end{tabular}


Table 4 (continued)

\begin{tabular}{lllll}
\hline Meteorological indicators & Coefficient & Std. Err. & $z$ & Probability \\
\hline Days & $0.014^{*}$ & 0.004 & 3.110 & 0.002 \\
Average temperature $\left({ }^{\circ} \mathrm{C}\right)$ & -0.011 & 0.046 & -0.241 & 0.809 \\
Rainfall per day $(\mathrm{mm})$ & 0.005 & 0.010 & 0.434 & 0.664 \\
Humidity per day $(\%)$ & $-0.027^{*}$ & 0.006 & -4.319 \\
\hline
\end{tabular}

*Significant at $1 \%$, significant at $5 \%$

distancing, personal hygiene, and use of mask and hand sanitizers.

Authors' contributions Ali Raza, Muhammad Tariq Iqbal Khan: conceptualization, methodology, software; Qamar Ali, Tanveer Hussain: data curation, writing - original draft preparation; Saadia Narjis: writingreviewing and editing.

Funding This research has no funding from any organization.

Availability of data and material Data will be available on request.

\section{Compliance with ethical standards}

Conflicts of interest The authors declare that they have no conflict of interest.

Ethical approval This article does not contain any studies with human participants or animals performed by any of the authors.

Consent to participate Not applicable

Consent to publish Not applicable

\section{References}

Ahmadi M, Sharifi A, Dorosti S, Ghoushchi SJ, Ghanbari N (2020) Investigation of effective climatology parameters on COVID-19 outbreak in Iran. Sci Total Environ 729:138705. https://doi.org/10. 1016/j.scitotenv.2020.138705

Ali G (2018) Climate change and associated spatial heterogeneity of Pakistan: empirical evidence using multidisciplinary approach. Sci Total Environ 634:95-108. https://doi.org/10.1016/j.scitotenv.2018. 03.170

Bashir MF, Ma B, Bilal KB, Bashir MA, Tan D, Bashir M (2020) Correlation between climate indicators and COVID-19 pandemic in New York, USA. Sci Total Environ 728:138835. https://doi.org/ 10.1016/j.scitotenv.2020.138835

Bi P, Wang J, Hiller JE (2007) Weather: driving force behind the transmission of severe acute respiratory syndrome in China? Intern Med J 37(8):550-554. https://doi.org/10.1111/j.1445-5994.2007.01358.x

Briz-Redón A, Serrano-Aroca A (2020) A spatio-temporal analysis for exploring the effect of temperature on COVID-19 early evolution in Spain. Sci Total Environ 728:138811. https://doi.org/10.1016/j. scitotenv.2020.138811

Brouwer AF, Weir MH, Eisenberg MC, Meza R, Eisenberg JNS (2017) Dose-response relationships for environmentally mediated infectious disease transmission models. PLoS Comput Biol 13(4): e1005481. https://doi.org/10.1371/journal.pcbi.1005481

Carico RR, Sheppard J, Thomas CB (2020) Community pharmacists and communication in the time of COVID-19: applying the health belief model. Res Soc Adm Pharm. https://doi.org/10.1016/j.sapharm. 2020.03.017

Chan KH, Peiris JS, Lam SY, Poon LLM, Yuen KY, Seto WH (2011) The effects of temperature and relative humidity on the viability of the SARS coronavirus. Adv Virol 2011:734690-734697. https:// doi.org/10.1155/2011/734690

Chen B, Liang H, Yuan X, Hu Y, Xu M, Zhao Y, Zhang B, Tian F, Zhu X (2020) Roles of meteorological conditions in COVID-19 transmission on a worldwide scale. medRxiv. https://doi.org/10.1101/2020. 03.16.20037168

Chuang YC, Lin HY, Chen PY, Lin CY, Wang JT, Chang SC (2016) Daptomycin versus linezolid for the treatment of vancomycinresistant enterococcal bacteraemia: implications of daptomycin dose. Clin Microbiol Infect 22:890.e1-890.e7

Consul PC, Famoye F (1992) Generalized poisson regression model. Commun Stat Theory Methods 21:89-109. https://doi.org/10. 1080/03610929208830766

Cupal M, Deev O, Linnertova D (2015) The poisson regression analysis for occurrence of floods. Proced Econ Financ 23:1499-1502. https://doi.org/10.1016/S2212-5671(15)00465-7

Dalziel BD, Kissler S, Gog JR, Viboud C, Bjørnstad ON, Metcalf CJE, Grenfell BT (2018) Urbanization and humidity shape the intensity of influenza epidemics in U.S. cities. Sci 362:75-79

Famoye F (1993) Restricted generalized Poisson regression model. Commun Stat Theory Methods 22:1335-1354

Famoye F (2014) A multivariate generalized Poisson regression model. Commun Stat Theory Methods 44:497-511. https://doi.org/10. 1080/03610926.2012.743565

Gale P, Brouwer A, Ramnial V, Kelly L, Kosmider R, Fooks AR, Snary EL (2010) Assessing the impact of climate change on vector-borne viruses in the EU through the elicitation of expert opinion. Epidemiol Infect 138(2):214-225. https://doi.org/10.1017/ s0950268809990367

Goswami K, Bharali S, Hazarika J (2020) Projections for COVID-19 pandemic in India and effect of temperature and humidity. Diabetes Metab Syndr Clin Res Rev 14:801-805. https://doi.org/ 10.1016/j.dsx.2020.05.045

Government of Pakistan (GOP) (2020a) http://covid.gov.pk/stats/ pakistan, Accessed date: 04 Oct 2020

Government of Pakistan (GOP) (2020b) Pakistan Meteriological Department. http://www.ffd.pmd.gov.pk/cp/ffd.php, Accessed date: 06 Sept 2020

Gupta S, Raghuwanshi GS, Chanda A (2020) Effect of weather on COVID-19 spread in the US: a prediction model for India in 2020. Sci Total Environ 728:138860. https://doi.org/10.1016/j.scitotenv. 2020.138860

Hajat S, Kosatky T (2010) Heat-related mortality: a review and exploration of heterogeneity. J Epidemiol Commun H 64(9):753-760. https://doi.org/10.1136/jech.2009.087999 
Hamadeh N, Karouni A, Daya B, Chauvet P (2017) Using correlative data analysis to develop weather index that estimates the risk of forest fires in Lebanon \& Mediterranean: Assessment versus prevalent meteorological indices. Case Stud Fire Saf 7:8-22. https://doi. org/10.1016/j.csfs.2016.12.001

Hussain M, Liu G, Yousaf B, Ahmed R, Uzma F, Ali MU, Ullah H, Butt AR (2018) Regional and sectoral assessment on climate-change in Pakistan: social norms and indigenous perceptions on climatechange adaptation and mitigation in relation to global context. J Clean Prod 200:791-808. https://doi.org/10.1016/j.jclepro.2018. 07.272

Jaakkola K, Saukkoriipi A, Jokelainen J, Juvonen R, Kauppila J, Vainio O, Ikäheimo TM (2014) Decline in temperature and humidity increases the occurrence of influenza in cold climate. Environ Health 13(1):22

Jahangiri M, Jahangiri M, Najafgholipour M (2020) The sensitivity and specificity analyses of ambient temperature and population size on the transmission rate of the novel coronavirus (COVID-19) in different provinces of Iran. Sci Total Environ 728:138872. https://doi. org/10.1016/j.scitotenv.2020.138872

Khan S, Khan M, Maqsood K, Hussain T, Noor-ul-Huda ZM (2020) Is Pakistan prepared for the COVID-19 epidemic? A questionnairebased survey. J Med Virol 92:824-832. https://doi.org/10.1002/ jmv. 25814

Kocsis T, Anda A (2018) Parametric or non-parametric: analysis of rainfall time series at a Hungarian meteorological station. Q J Hungarian Meteorol Ser 122(2):203-216. https://doi.org/10.28974/idojaras. 2018.2.6

Li X, Wang N, Ding G, Li X, Xue X (2019) The relationship between meteorological factors and the risk of bacillary dysentery in Hunan Province, China. Weather 74(4):148-153

Liu J, Zhou J, Yao J, Zhang X, Li L, Xu X, He X, Wang B, Fu S, Niu T, Yan J, Shi Y, Ren X, Niu J, Zhu W, Li S, Luo B, Zhang K (2020) Impact of meteorological factors on the COVID-19 transmission: A multicity study in China. Sci Total Environ 726:138513. https://doi. org/10.1016/j.scitotenv.2020.138513

Ma Y, Zhao Y, Liu J, He X, Wang B, Fu S, Yan J, Niu J, Zhou J, Luo B (2020) Effects of temperature variation and humidity on the death of COVID-19 in Wuhan, China. Sci Total Environ 724:138226. https://doi.org/10.1016/j.scitotenv.2020.138226

Maxwell O, Mayowa BA, Chinedu IU, Peace AE (2018) Modelling count data; a generalized linear model framework. Am J Math Stat 8(6):179-183. https://doi.org/10.5923/j.ajms.20180806.03

Prata DN, Rodrigues W, Bermejo PH (2020) Temperature significantly changes COVID-19 transmission in (sub) tropical cities of Brazil. Sci Total Environ 729:138862. https://doi.org/10.1016/j.scitotenv. 2020.138862

Şahin M (2020) Impact of weather on COVID-19 pandemic in Turkey. Sci Total Environ 728:138810. https://doi.org/10.1016/j.scitotenv. 2020.138810

Sajadi MM, Habibzadeh P, Vintzileos A, Shokouhi S, Miralles-Wilhelm F, Amoroso A (2020) Temperature and latitude analysis to predict potential spread and seasonality for COVID-19. Available at SSRN 3550308

Shi P, Dong Y, Yan H, Zhao C, Li X, Liu W, He M, Tang S, Xi S (2020) Impact of temperature on the dynamics of the COVID-19 outbreak in China. Sci Total Environ 728:138890. https://doi.org/10.1016/j. scitotenv.2020.138890

Sobral MFF, Duarte GB, Sobral AIGDP, Marinho MLM, Melo ADS (2020) Association between climate variables and global transmission of SARS-CoV-2. Sci Total Environ 729:138997. https://doi.org/10.1016/j.scitotenv.2020.138997

Stott P (2016) CLIMATE CHANGE. How climate change affects extreme weather events. Sci 352(6293):1517-1518. https://doi.org/10. 1126/science.aaf7271

Sullivan PJ, Agardy FJ, Clark JJJ (2005) CHAPTER 4-Living with the Risk of Polluted Water. The Environmental Science of Drinking Water, Butterworth-Heinemann, Pages 143-196, ISBN 9780750678766, https://doi.org/10.1016/B978-075067876-6/ 50007-5

Syed F, Sibgatullah S (2020) Estimation of the final size of the COVID19 epidemic in Pakistan. medRxiv. https://doi.org/10.1101/2020.04. 01.20050369

Tosepu R, Gunawan J, Effendy DS, Ahmad LOAI, Lestari H, Bahar H, Asfian P (2020) Correlation between weather and Covid-19 pandemic in Jakarta, Indonesia. Sci Total Environ 725:138436. https://doi.org/10.1016/j.scitotenv.2020.138436

Wang P, Goggins WB, Chan EY (2018) A time-series study of the association of rainfall, relative humidity and ambient temperature with hospitalizations for rotavirus and norovirus infection among children in Hong Kong. Sci Total Environ 643:414-422. https://doi. org/10.1016/j.scitotenv.2018.06.189

Wang J, Tang K, Feng K, Lv W (2020a) High temperature and high humidity reduce the transmission of COVID-19. Available at SSRN 3551767

Wang M, Jiang A, Gong L, Luo L, Guo W, Li C, Zheng J, Li C, Yang B, Zeng J, Chen Y, Zheng K, Li H (2020b) Temperature significant change COVID-19 transmission in 429 cities. medRxiv. https://doi. org/10.1101/2020.02.22.20025791

World Health Organization (WHO) (2020) World Heath Organization. https://www.who.int/emergencies/diseases/novel-coronavirus2019/situation-reports/, Accessed date: 04 Oct 2020

World Weather Online (2020) World Weather Online. https://www. worldweatheronline.com/, Accessed date: 06 Sept 2020

Wu Y, Jing W, Liu J, Ma Q, Yuan J, Wang Y, Du M, Liu M (2020) Effects of temperature and humidity on the daily new cases and new deaths of COVID-19 in 166 countries. Sci Total Environ 729: 139051. https://doi.org/10.1016/j.scitotenv.2020.139051

Xie J, Zhu Y (2020) Association between ambient temperature and COVID-19 infection in 122 cities from China. Sci Total Environ 724:138201. https://doi.org/10.1016/j.scitotenv.2020.138201

Ye T, Liu W, Mu Q, Zong S, Li Y, Shi P (2020) Quantifying livestock vulnerability to snow disasters in the Tibetan Plateau: Comparing different modeling techniques for prediction. Int J Disaster Risk Reduct 48:101578

Yuan J, Yun H, Lan W, Wang W, Sullivan SG, Jia S, Bittles AH (2006) A climatologic investigation of the SARS-CoV outbreak in Beijing, China. Am J Infect Control 34:234-236. https://doi.org/10.1016/j. ajic.2005.12.006

Zhu Y, Xie J (2020) Association between ambient temperature and COVID-19 infection in 122 cities from China. Sci Total Environ 727:138704. https://doi.org/10.1016/j.scitotenv.2020.138704

Zu ZY, Jiang MD, Xu PP, Chen W, Ni QQ, Lu GM, Zhang LJ (2020) Coronavirus disease 2019 (COVID-19): a perspective from China. Radiol 200490:E15-E25. https://doi.org/10.1148/radiol. 2020200490

Publisher's note Springer Nature remains neutral with regard to jurisdictional claims in published maps and institutional affiliations. 